\title{
Existing Breeding Management Practices by the Farmers of Kanpur Nagar, Uttar Pradesh
}

\author{
Deepak Singh, Ved Prakash, P. K. Upadhyay, M. P. S. Yadav, \\ Narendra Kumar and Satendra Kumar
}

\author{
Department of Animal Husbandry \& Dairying, Chandra Shekhar Azad university of \\ Agriculture and Technology, Kanpur, (U.P.), India \\ *Corresponding author
}

\section{A B S T R A C T}

\section{Keywords}

Buffalo, Farmers, Breeding, Heat

\section{Article Info}

\section{Accepted:}

07 January 2021

Available Online:

10 February 2021
The result of buffalo breeding in the different two blocks Bilhaur and Kalyanpur. These two blocks selected from Kanpur Nagar district of Uttar Pradesh revealed that in the study only 28.00 per cent of the farmers rearing descript buffalo in the study area. It was concluded that in my study more than half 51.00 per cent of the farmers adopted both A.I. and natural breeding and most of the 42.50 per cent farmers were heat detection by mucus discharge + bellowing. The majority of the farmers 52.50 per cent were reported expelled placenta within two hours. It was found according to my village's study noted that buffaloes were allowed for insemination at mid-heat by 82.00 per cent of farmers and pregnancy diagnosis not done by most of the farmers 62.00 per cent in the villages. Most of the farmers 57.50 per cent animals take 3-4.5 year time for first calving. 81.50 per cent of farmers treated the anoestrus as their animals in the villages. Mostly 59.00 per cent of the farmers buffaloes were taken less than 18 month calving interval. These all information obtained from 200 farmers of the district of Uttar Pradesh.

\section{Introduction}

Buffaloes in the world are categorized into two species: the numerous Asiatic water buffalo (Bubalus bubalis) and African buffalo (Syncerus Gaffer). Asiatic Water buffalo two subspecies are known, the river $(2 n=50)$ and the swamp $(2 \mathrm{n}=48)$ buffalo. River buffalo are the most numerous species include the Murrah, Jafarabady, Surti, Mehsana, Egyptian and Mediterranean breeds (Iannuzzi, 1994). India is leading the world in milk production since 1998 and produced 165.4 million tonnes of milk with per capita availability of milk 335 grams during 2016-17. Buffalo shared about 49.2 per cent of the total milk produced in India (Anonyms, 2018). Buffaloes contribute 30 per cent total meat in the country. Buffaloes are great producers of milk and fulfill the great demand of meat. The major states of buffalo meat production are Uttar Pradesh followed by Andhra Pradesh and Maharashtra.

In the encouragement of the national economy of India, the Livestock sector plays 
a major role and also increases the growth rate. Due to the lack of detailed information on the animals farming existing breeding practices adopted for different categories of livestock, it's not possible for the policy planners to give full attention to these important aspects of dairy cattle production. Efficient management requires a strong database.

Efforts should aim to collect information related to animal rearing. Few efforts are known to have been made to study systematic information related to livestock farming and its management adopted in the village. This has not been adequate to serve as the basis on which valid guidelines for introducing scientific managerial practices for improvements of livestock dairy animals can be framed.

\section{Materials and Methods}

The study was conducted purposively in the central zone of Uttar Pradesh. Kanpur occupies the north-western part of the Kanpur division. The present study was conducted by comprising two different blocks Bilhaur and Kalyanpur of Kanpur Nagar district of U.P. The study area has more buffalo population. In each block, Ten villages were selected, and also in all these villages ten farmers were selected randomly have vast opportunities for rural development through buffalo. During summer the temperature of the Kanpur district is very high temperature compared to another district of U.P. The Kanpur lies $132 \mathrm{~m}$ above sea level and the climate in Kanpur is warm and temperate. When compared with winter, the summers have much more rainfall. The average annual temperature is $25.6{ }^{\circ} \mathrm{C} \mid 78.1$ ${ }^{\circ} \mathrm{F}$ in Kanpur. The annual rainfall is $820 \mathrm{~mm}$ (32.3 inches). Statistical tools percentage using the methods suggested by Snedecor and Cochran (1994).

\section{Results and Discussion}

The finding regarding various breeding practices followed by farmers in given table 1. The role of breeding is very important to generate sufficient stock of improved germplasm for better productivity and healthy animal in the district. The overall result comes from table 1 indicated that 72.00 per cent were reared non-descript buffaloes only 28.00 per cent reared descript buffaloes like Murra, Bhadawari. This finding is well comparable with the findings of Dhaka et al., (2017). That is because descript buffaloes are costly and farmers were not able to pay more money.

It was concluded that in my study more than half 51.00 per cent of the farmers adopted both A.I. and natural breeding, while 36.50 per cent preferred only A.I. and 12.50 per cent farmers adopted natural service in the block of the district.

The present findings were in close agreement with reported by Sekhar et al., (2017), Yadav et al., (2016). Some of the contradicted by Chakravarthi et al., (2017), Godara et al., (2018b) found that most of the farmers used A.I. practices at the time of breeding.

Heat detection was observed that by the farmers 42.50, 27.50, 20.00, and 10.00 per cent through mucus discharge + bellowing, mucus discharge, mucus discharge + bellowing + mounting and off feed + urine discharge as the main sign of estrous. This finding is well comparable with finding of Khadda et al., (2017), Kumar et al., (2019a), Kumar et al., (2020), Singh (2018), Viswkarma et al., (2018), Yadav et al., (2016) farmers used mucus and bellowing together for heat detection in animals. Mucus discharge and bellowing is the main sign and farmers assure that buffalo in heat. 
Table.1 Existing breeding management practices

\begin{tabular}{|c|c|c|c|c|}
\hline Existing practices & Bilhaur & Kalyanpur & Farmers & Per cent \\
\hline \multicolumn{5}{|l|}{ 1. Breed of buffalo } \\
\hline A. Descript buffalo & 23 & 33 & 56 & 28.00 \\
\hline B. Non descript buffalo & 77 & 67 & 144 & 72.00 \\
\hline \multicolumn{5}{|l|}{ 2. Method of breeding } \\
\hline A. Natural & 20 & 05 & 25 & 12.50 \\
\hline B. A.I. & 36 & 37 & 73 & 36.50 \\
\hline C. Both & 44 & 58 & 102 & 51.00 \\
\hline \multicolumn{5}{|l|}{ 3. Method of heat detection } \\
\hline A. Mucous discharge + bellowing & 40 & 45 & 85 & 42.50 \\
\hline B. Mucous discharge + off feed & 12 & 08 & 20 & 10.00 \\
\hline $\begin{array}{l}\text { C. Mucous discharge + bellowing } \\
\text { +mounting }\end{array}$ & 18 & 22 & 40 & 20.00 \\
\hline D. Mucous discharge & 30 & 25 & 55 & 27.50 \\
\hline \multicolumn{5}{|l|}{ 4. Expulsion of placenta } \\
\hline A. Within 1 hour & 38 & 28 & 66 & 33.00 \\
\hline B. Within 2 hour & 45 & 60 & 105 & 52.50 \\
\hline C. More than 2 hour & 17 & 12 & 29 & 14.50 \\
\hline \multicolumn{5}{|c|}{ 5.Stage of heat which buffalo allowed for insemination/service } \\
\hline A. Early heat & 10 & 06 & 16 & 08.00 \\
\hline B. Mid heat & 78 & 86 & 164 & 82.00 \\
\hline C. Later heat & 12 & 08 & 20 & 10.00 \\
\hline \multicolumn{5}{|l|}{ 6. Pregnancy diagnosis } \\
\hline A. By experience farmers & 31 & 25 & 56 & 28.00 \\
\hline B. By veterinary doctors & 04 & 16 & 20 & 10.00 \\
\hline C. Not done & 65 & 59 & 124 & 62.00 \\
\hline \multicolumn{5}{|l|}{ 7. Age at first calving } \\
\hline A. Within 3 year & 00 & 06 & 06 & 03 \\
\hline B. 3-4.5 year & 49 & 66 & 115 & 57.5 \\
\hline C. 4.5-6 year & 51 & 28 & 79 & 39.5 \\
\hline \multicolumn{5}{|l|}{ 8. Treatment of anoestrous/repeaters } \\
\hline A. Yes & 77 & 86 & 163 & 81.5 \\
\hline B. No & 23 & 14 & 37 & 18.5 \\
\hline \multicolumn{5}{|l|}{ 9. Breeding after calving } \\
\hline A. Within 3 months & 00 & 00 & 00 & 00 \\
\hline B. 3-6 months & 68 & 54 & 122 & 61.00 \\
\hline C. More than 6 months & 32 & 46 & 78 & 39.00 \\
\hline \multicolumn{5}{|l|}{ 10. Calving interval } \\
\hline A. More than 18 month & 83 & 35 & 118 & 59.00 \\
\hline B. Less than 18 month & 17 & 65 & 82 & 41.00 \\
\hline
\end{tabular}


The study shows that the majority of the farmers 52.50 per cent was reported expelled placenta within two hours and followed that by the 33.00 per cent take one hour after calving but 14.50 per cent take more than two hours in the study area. The observation and findings of the study were in favor of finding reported by Singh et al., (2016).

All the farmers observed their buffaloes for heat symptoms regularly. It was found according to my village's study noted that buffaloes were allowed for insemination 82.00 per cent and 10.00 per cent of the farmers followed the practice in mid-heat and later heat, respectively, whereas only 08.00 per cent observed to detect heat in an early stage. This is the support of the study with Kumar et al., (2019a), Kumar et al., (2020), Singh (2018), Singh et al., (2019a).

It was noted that pregnancy diagnosis not done by most of the farmers 62.00 per cent in the villages and 28.00 per cent farmers were pregnancy diagnosis done by experienced farmers and only 10.00 per cent by the qualified veterinarian in the study area. The results are in line with the findings of Dar et al., (2017), Tanwar et al.(2012), Sreedhar et al., (2017a), Singh (2018), Malsawmdawngliana and Rahman (2016). It was contradicted the study found that most farmers' pregnancy diagnosis was done Khadda et al., (2017). It was observed from my study that most of the farmers were not observed pregnancy diagnosis by the farmers because of lack of knowledge and experience about the pregnancy farmers don't know how to detect pregnancy of the buffaloes.

The study found that most of the farmers 57.50 per cent animals taken 3-4.5 year time for first calving followed that more than 4.5-6 year time takes by the 39.50 per cent buffaloes and only 03.00 per cent buffaloes first calving within 3 years of age. These were in agreement with Dhaka et al., (2017), Meena et al., (2016) first calve at $1288 \pm 122$ day, Singh et al., (2016).

The result indicated that all the farmers treated their buffaloes for anestrous, repeat breeding, and sometimes infertility problem. It was found that 81.50 per cent of farmers treated the anoestrus and 18.50 per cent of farmers not treated their animals in the villages. These results are in consonance with the findings of Khadda et al., (2017), Sivaji et al., (2018), and this observation highly contradicted by the Malsawmdawngliana and Rahman (2016).

It was observed that 61.00 per cent buffaloes successive breeding done 3-6 months after calving followed that 39.00 per cent breeding done after 6 months of calving. Similar findings were reported by Kumar et al., (2020), Malsawmdawngliana and Rahman (2016), Singh (2018), Singh et al., (2019a), Yadav et al., (2016), Sekhar et al., (2017).

It was found in the study mostly 59.00 per cent of the respondent's buffaloes were taken more than 18 months of calving interval and only 41.00 per cent calving after 18 months. These were in agreement with Dhaka et al., (2017), Singh (2018), Sreedhar et al., (2017a) found 73.75 per cent were taking more than 18 months' time. Meena et al., (2016) observed that the calving interval of buffaloes is $495 \pm 45$. Calving interval is more in the buffaloes this is because of repeated breeding and due to lack of feeding management.

In conclusion it was noticed that in the study most of the farmers of Kanpur Nagar prefer that both methods of insemination. Repeat breeding and anoestrus are highly affected to the dairy buffaloes this is because of hot weather in summer and poor management practices used by the farmers. This is also observed that pregnancy diagnosis is not done 
by most of the farmers because of lack of awareness. It was found in the study mostly 59.00 per cent of the respondent's buffaloes were taken more than 18 months of calving interval because of lack of managemental practices adopted by the farmers in the district.

\section{References}

Anonyms, (2018). Annual report 2017-18. Department of Animal Husbandry, Dairying and Fisheries, GOI. pp. 2-3.

Chakravarthi Dr. M. Kalyana, Bharadwaja Dr. Marella, Kumar Kutty, Dr. Potu Ramesh Babu (2017). Extent of Adoption of Improved Animal Husbandry Ppractices by Dairy Farmers in Kadapa District of Andhra Pradesh. International Journal of Science, Environment and Technology, 6(5): $2815-2820$.

Dar P.A., Khan. A. A., Ahmad A., Qadri. I. A., Manzoor Ashiq., Khan Hilal Musadiq., (2017) Studies on Breeding and Feeding Practices of Buffalo in Vogue among Buffalo Farmers in Temperate Himalayan Region of Kashmir Valley. Indian Journal of Hill Farming, Page No.- 83-87.

Dhaka B.L., Meena G.S. and Meena N.L.(2017). Reproductive Performance of Buffaloes under Field Conditions in Bundi District of Rajasthan, India. Int.J.Curr.Microbiol.App.Sci. 6(4): 595599.

Godara Vikas, Gulati Harish Kr., Singh Narender and Robin (2018). Buffalo Breeding Management Practices Followed by Farmers of Western Haryana. J Krishi Vigyan, 6(2): 13-16.

Iannuzzi L. (1994) Standard karyotype of the river buffalo (Bubalus bubalis L., $2 \mathrm{n}=$ 50). Cytogenetics and Cell Genetics, 67:102-113.

Khadda B.S., Lata Kanak, Singh Brijesh and
Kumar Raj (2017). Study of buffalo husbandry practices in rural area of central Gujarat in India, Buffalo Bulletin (January-March 2017) Vol.36 No.1: 75-87.

Kumar Avanish., Kumar Vipin., Upadhyay., Singh V.P. (2020). Existing Dairy Husbandry Practices followed by Livestock owners in Farrukhabad District of Uttar Pradesh, India. Int.J.Curr.Microbiol.App.Sci (2020) 9(2) Pg. No.-: 1863-1873.

Kumar J., Singh R., Dayal Somnath, Rajeshwar, Singh Hitesh and Singh Satyveer (2019). Studies on feeding \& breeding practices of dairy animal in western Uttar Pradesh. Journal of Pharmacognosy and Phytochemistry. Pg. No.-: 29-36.

Malsawmdawngliana R., and Rahman S., (2016). Management practices followed by the dairy farmers of Mizoram, India. Journal of Livestock Science, 7: Pg. No.220-225.

Meena B.S., Verma H.C. and Singh Amit (2016). Farmer's knowledge on Productive and Reproductive Performances of Buffalo under Small Holder Farming System. Buffalo Bulletin (March 2016) Vol.35 No.1: 101-108.

Sekhar M.R., Rajanna N., Mahendra M., and Chaudhary S. (2017). Comrative study of feeding and breeding management practices of dairy farmers in two different production systems. Asian J. Dairy \& Food Res, 36(4). Pg. No.-: 269-275.

Singh R. (2018). Existing Animal Husbandry Practices in Narmada District of Gujarat in India. International Journal of Animal Science and Technology. Vol. 2, No. 2 (2): pp. 23-29.

Singh R., Kumar P., Khandi S.A. and Bhadwal M.S. (2016). Animal welfare practices followed by dairy farmers of 
Kathua district of Jammu and Kashmir State. Journal of animal research 6(3): 479-491.

Sivaji D.V., Natchimuthu K., Ramkumar S., Sreekumar D., Ganesan R. (2018). A Study on Adoption of Buffalo Husbandry Practices in Guntur and Prakasam Districts of Andhra Pradesh. Res J. Chem. Environ. Sci. Vol 6 [3] June 2018: 35-39.

Snedecor G.W. and Cochran W.G. (1994) "Statistical methods," 8th Edition, Iowa State University Press, Ames,.

Sreedhar S., Reddy A. Nagarjuna, Sudhakar B.V. and Babu P. Ramesh (2017). Breeding management practices and Reproductive Disorders in Indigenous Cattles and Buffaloes. Global Journal of bio-science and biotechnology, 6 (3): 504-508.
Tanwar P.S., Kumar Yogendra and Sankhala Gopal (2012). Study on Breeding and Feeding Management Practices Followed By Members and Nonmembers of Dairy Cooperatives in Jaipur District Of Rajasthan. Indian J. Dairy Sci. 65(6). Pg. No. 508-513.

Viswkarma, Singh Ruchi, Kushram Priyanka, Singh Sandeep Kumar and Sharma Shivangi (2018). Existing status of buffalo husbandry practices in Jabalpur. The Pharma Innovation Journal; 7(2): 08-11.

Yadav S.P., Paswan V.K., Sawant P. and Bhinchhar B.K. (2016). Breeding and calf rearing management practices followed in Varanasi district of Uttar Pradesh, India. Indian J. Anim. Res., 50 (5): 799-803.

\section{How to cite this article:}

Deepak Singh, Ved Prakash, P. K. Upadhyay, M. P. S. Yadav, Narendra Kumar and Satendra Kumar. 2021. Existing Breeding Management Practices by the Farmers of Kanpur Nagar, Uttar Pradesh. Int.J.Curr.Microbiol.App.Sci. 10(02): 625-630. doi: https://doi.org/10.20546/ijcmas.2021.1002.074 